\title{
Analysis of Abnormal Operating Performance Between Family Owned Firms and State Owned Firms in Indonesia and Malaysia
}

\author{
Citra Sukmadilaga $^{1}$ \& Erlane K Ghani ${ }^{2}$ \\ ${ }^{1}$ Department of Accounting, Faculty of Economics and Business, Universitas Padjadjaran, Indonesia \\ ${ }^{2}$ Faculty of Accountancy, Universiti Teknologi MARA, Malaysia \\ Correspondence: Erlane K Ghani, Faculty of Accountancy, Universiti Teknologi MARA, Malaysia.
}

Received: April 20, 2019

doi:10.5430/ijfr.v10n3p107
Accepted: May 7, 2019

Online Published: May 19, 2019

URL: https://doi.org/10.5430/ijfr.v10n3p107

\begin{abstract}
Purpose: This study examines the financial performance of family owned firms and state owned firms listed in Bursa Malaysia and the Indonesia Stock Exchange.

Design/Methodology/Approach: This study employed abnormal operating performance to measure firm performance over a 15 year period from 1992 to 2007.

Findings: This study shows that the state owned firms outperformed the family owned firms in Indonesia and Malaysia. Hence, the family owned firms need to strategize on how to increase its competitive advantage in order to compete with the state owned firms especially if they are competing in similar industry. Based on abnormal operating performance result, for each type of ownership which have model that have influenced by changing in their internal company or changing within their industry, they need to consider all factors that can impact their performance.

Practical Implications: This study may assists the family owned and government involvement in company and their performance.

Originality/Value: This study contributes to the existing literature by providing a new data set on family and government owned companies in both countries.
\end{abstract}

Keywords: ownership concentration, family ownership, state/government ownership, abnormal operating performance

JEL code: M40, M41

\section{Introduction}

The relationship between ownership structure and firm performance has long been the core issue in the accounting literature ever since Berle and Means (1932) predicted that firm performance would improve if the ownership is more concentrated. From a firm's perspective, ownership structure determines the firm's profitability, enjoyed by different stake-holders. In particular, ownership structure is an incentive device to reduce agency costs associated with the separation of ownership and management, of which can be used to protect property rights of the firm (Barbosa \& Louri, 2002; Castorena., Enríquez, \& Adame, 2014; Dim \& Ezeabasili, 2015; Wang \& Lu, 2016). Often, firms owned by various shareholders that are controlled by the managers tend to underperform (Berle \& Means (1932). However, such arrangement often leads to agency problem (Jensen, 1983). That is, the main agency problem is not really on the manager-shareholder conflict but rather on the risk of expropriation by dominant or controlling shareholders at the expense of the minority shareholders.

Claessens, Djankov, Fan and Lang (2002) reported that in the Asian region, Indonesia has the highest percentage of firms with family ownership, followed by Malaysia. Meanwhile, Malaysia has the second highest percentage of firms with state ownership, followed by Indonesia. This is consistent with Lassere and Schutte (1999) that claimed beside the family business, in most parts of Asia (with exception of Hong Kong and Japan), state participation in the business sector has been an integral part of the industrialisation process. Claessens et al (2002) revealed that in Indonesia, from the 178 samples of public listed firms in 1996, 71.5 percent of the firms are family owned firms whilst 8.2 percent of the firms are state owned firms. In Malaysia, Claessens et al (2002) found that 238 sample firms 
are public listed firms listed in 1996, 67.2 percent and 13.4 percent of the sample firms are categorised as family owned and state owned firms respectively. On the other hand, Samad, Amir and Ibrahim (2008) reported that 43 percent of the public listed firms registered on the Bursa Malaysia over a period of 6 years from 1999 to 2005 are family owned firms. Meanwhile, Ab Razak, Ahmad and Aliahmed (2008) found that family owned firms and state owned firms accounted for approximately RM260 billion or approximately 54 percent and 36 percent respectively of the market capitalisation of Bursa Malaysia and benchmark Kuala Lumpur Composite Index. Arguably, the high percentage of these firms in the capital market is more likely to impact the economy of their country.

Within the accounting literature, a large number of studies have examined the link between ownership concentration and firm performance. However, nearly all documented evidences are obtained in the developed countries, leaving little evidence on the relationship between ownership concentration and firm performance in the developing countries particularly in the less developed South East Asian countries. Since many economies in the less developed South East Asian countries are characterized by considerable family owned firms and state ownership firms (Claessens, Djankov \& Lang, 2000; Duru \& Chibo, 2014; Purnama, 2014; Nazal, 2017; Tanoos, 2017; Taqi., Ajmal \& Ansari, 2018; Chowdhury., Habibullah \& Nahar, 2018), it would be interesting to examine the link between ownership concentration and firm performance in the South East Asian countries such as Indonesia and Malaysia. In addition, this study provides evidence on whether the findings on the link between ownership concentration and firm performance for developing countries would be similar to the findings in the developed countries despite the fact that the institutional conditions in the developing countries, particularly those with respect to markets and organisations, are significantly different from those in the developed countries (Nze., Ogwude., Nnadi, \& Ibe, 2016; Kimengsi \& Gwan, 2017; Cheng., Phung., Hsiao., Shen \& Chen, 2018 ; CHE \& Sundjo, 2018).

This study examines the link between ownership concentration and firm performance in developing countries. Specifically, this study provides comparative analysis on the family owned firms and state owned enterprise between two developing countries namely, Indonesia and Malaysia. The findings in this study would provide interesting point of discussion on the link between ownership concentration and firm performance. The remainder of this study is structured as follows. The next section, Section 2 provides the literature review related to integrated reporting practices and subsequently, the development of the research question and research hypotheses. Section 3 outlines the research design. The findings of this study are presented in Section 4. The final section summarises and concludes this study.

\section{Literature Review}

The theory of the firm presumes that in a perfect market, all firms are competing for resources and markets on an even level. However, in reality, this is not true for high ownership concentrated firms. Coase (1937) argued that the firm controls the transformation of resources it owns or purchases into valuable products that it sells and earns the difference between what it receives as revenue and what it spends on inputs. Claessens et al (2000) classified ownership concentration into two main groups namely, widely held firms and firms with ultimate controlling owners. In a widely held firm, none of the owners possess a significant control right whereas a firm with ultimate controlling owners have certain shareholders who have control in some percentages of the voting right and can be traced in the chain of ownership. Claessens et al (2000) further divided ultimate owners into family owned firms and state owned firms.

Wong (2004) discussed about how state owned firms affect firm performance. He claimed that unlike private firms, which focus exclusively on profit maximization, most state owned firms pursue multiple-and conflicting-objectives. Multiple objectives arise either because they are mandated by legislation or because of the different government ministries that have the position to exert influence on the state owned firms. The latter situation becomes special problematic if the ministries have different aims for their state owned enterprise and do not reconcile their divergent views. Although the taxpayers are the ultimate owners of state owned firms, they rely on the politicians and bureaucrats to be their agents. In other words, the taxpayers rely on the ministries namely, the politicians and bureaucrats to look after their interests. Politicians and bureaucrats however, are typically poor overseers of state owned firms since they are also self-interested individuals who may have the tendency to attain, exploit and maintain power. Politicians and bureaucrats are also poor agents because they do not benefit-financially and if the state owned firms are highly profitable, the politicians and bureaucrats may be blamed when their state owned enterprise acts "too commercially" or things go wrong.

In relation to family owned firms, family owned firms that have long term presence of founding families within firms can also engender competitive advantages. First, the family's lengthy tenure can extend the firm's learning curve in monitoring employee performance. Secondly, James (1999) has indicated that families tend to maintain longer 
investment horizons than others shareholders, who may make myopic investment decisions that boost current or short term earnings. Family owned firms may also invest more efficiently because they may view their firms as an asset to pass on to succeeding generations. The family's longer outlook also implies a more vital role of firm survival among family owned firms. Arguably, family owned firms could also generate competitive advantages.

Many studies have highlighted the complexity of running a family business. Davis (1983) and Lansberg (1983) found that family owned firms often create many unique challenges. Such challenges include the balance between equity and efficiency and the problem of succession. Other studies highlighted the power an incentives of founding families to act in their own interest at the expense of firm performance. Shleifer and Summers (1988) and Shleifer and Vishny (1997) posited that firms with largely undiversified owners such as founding family members, may forego maximum profits when they are unable to separate their own financial preferences from those of other owners outside the family. Demsetz (1983) argued that family business owners may also choose no pecuniary benefits and thus, draw resources away from profitable projects. Moreover, the family is likely to limit top management positions to family members rather than hire more qualified or competent outsiders. Family members are capable of redistributing benefits from the firm through excessive compensation or special dividends that may adversely affects employee morale and productivity. For public firms, founding families may have interest of their own, such as stability and capital preservation, which may not be consistent with the interest of other investors.

Studies in the developed countries often revealed that ownership concentration has positive impact on firm performance (Mitton, 2002; Claessens \& Fan, 2002). However, there are also studies in the developed countries that found no significant relationship between ownership concentration and firm performance (Demsetz \& Villalonga, 2000; Kocenda \& Svejnar, 2002). The findings of these studies however are inconclusive which could be attributed by the various specifications of performance measurements. When examining the effect of ownership concentration on firm performance, extant literature often used two performance measures such as: (1) operating efficiency, measured by return on total assets, and (2) the market-to-book ratio of assets. The first measure is used to test the hypothesis that concentrated ownership improves firm efficiency. The second measure is used to examine the market assessment of firm value, given existing policy combinations and operating efficiency.

The literature further suggested that concentrated ownership affects operating efficiency in two ways: (1) the presence of a large shareholder mitigates managerial agency problem and improves operating efficiency (Grossman \& Hart 1980, Shleifer \& Vishny, 1986); and (2) large shareholders may behave opportunistically for their private benefits which may lead to inefficient resource allocation such as buying or selling assets of firms under their control at prices unfair to minority shareholders. A study of Korean firms by Joh (2003) finds that the controlling shareholders' cash flow rights are positively related to firm efficiency measured by return of total assets (ROA) whereas the divergence between control and cash flow rights of the controlling owner is negatively related to ROA. This study anticipates that the findings of this study would be similar to the findings shown in the developed countries. Thus, this study develops the first hypothesis:

$\mathrm{H}_{0}$ : Family owned firms and state owned firms listed in the Bursa Malaysia and the Indonesian Stock Exchange (IDX) have abnormal operating performance equal to zero.

\section{Research Design}

\subsection{Sample Data}

This study chose the family owned firms and state owned firms to be the sample of this study. The annual reports of these firms which were obtained from the Indonesian Stock Exchange (IDX) and Bursa Malaysia. Specifically, this study relied on the financial statements and the SIC codes to obtain the objectives of this study. This study obtained the annual reports over a period of 25 years consisting of three phases. The three phases are Pre Crisis (1992 until 1996), Crisis (1997 until 2000) and Post Crisis (2001 until 2007).

\subsection{Variable Measurement}

In this study, the financial ratios are treated as the non-frontier analysis. This study used the Abnormal Operating Performance (APO) which is based on the choice of an accounting-based performance measure, a statistical test, and a model of expected operating performance. This study used five measurement of operating performance:

1. Return on assets (Operating income scaled by the book value of assets),

2. Return on cash-adjusted assets (Operating income scaled by the book value of assets less cash and marketable securities),

3. Return on sales (operating income scaled by sales),

4. Return on market value of assets (operating income scaled by the market value of assets), and

5. Cash flow return on assets (operating cash flow scaled by the book value of assets). 
This study used the Non-parametric Wilcoxon signed-rank T as defined by Barber and Lyon (1996) whereby the non-parametric test more powerful compare to parametric test in term of detecting abnormal operating performance. This study then compared seven models of expected operating performance used in recent empirical work in the academic finance and accounting literature. In analysing the abnormal operating performance, there are three emerging points in each country: First, from the seven models, the result would reveal the most powerful model in detecting abnormal operating performance based on the highest R-squared. Secondly, the statistic test result from the Non parametric Wilcoxon $\mathrm{T}$ would present the model that is most significant, indicating that the research hypothesis would be rejected and the combination between the first and the second result would propose the ultimate model that can detect the abnormal operating performance the best. Third, the analysis of sub period defines the type of ownership concentration that performs better.

\section{Results and Discussion}

\subsection{Indonesian Abnormal Operating Performance}

This section presents the results of the abnormal operating performance of the family owned firms and state owned firms in Indonesia. Table 1 shows the combination results between adjusted $\mathrm{R}^{2}$ and non-parametric Wilcoxon test statistic reveals that Indonesia family owned firms have model 1 (Level of industry performance with two digit SIC matched) as the most explanatory power in detecting abnormal operating performance. However, since the rest proposed models are significant, they are qualified as candidates for detecting abnormal operating performance. Meanwhile, the result for Indonesian state owned firms shows that model 6 (lagged firm performance and change in industry performance with two-digit SIC and size matched) is the model with the most explanatory power that uses lagged firm performance and change in industry performance.

Table 1. Indonesian family owned firms

\begin{tabular}{ll}
\hline Model & Nonparametric Wilcoxon $\mathrm{T}$ \\
\hline 1: Two-digit matched $\left(\mathrm{PI}_{\mathrm{i}, \mathrm{t}}{ }^{1}\right)$ & $0.008^{* *}$ \\
\hline 2: Four-digit matched $\left(\mathrm{PI}_{\mathrm{i}, \mathrm{t}}{ }^{2}\right)$ & 0,650 \\
\hline 3: Two-digit and size-matched $\left(\mathrm{PI}_{\mathrm{i}, \mathrm{t}}{ }^{3}\right)$ & 0,112 \\
\hline 4: Lagged ROA and $\Delta$ two-digit matched $\left(\Delta \mathrm{PI}_{\mathrm{i}, \mathrm{t}}{ }^{1}\right)$ & $0.001^{* *}$ \\
\hline 5: Lagged ROA and $\Delta$ four-digit matched $\left(\Delta \mathrm{PI}_{\mathrm{i}, \mathrm{t}}{ }^{2}\right)$ & $0.001^{* *}$ \\
\hline 6: Lagged ROA and $\Delta$ two-digit and size matched $\left(\Delta \mathrm{PI}_{\mathrm{i}, \mathrm{t}}{ }^{3}\right)$ & $0.001^{* *}$ \\
\hline 7: Lagged ROA $\left(\mathrm{P}_{\mathrm{i}, \mathrm{t}-1}\right)$ & 0.307 \\
\hline
\end{tabular}

Significant at the $5 \%(*)$ and $1 \%(* *)$ levels

Table 2 presents the results of the statistical test for Indonesian state owned firms. The results model 6 has positive number for Pre Crisis and Crisis period as shown in Table 2. However in the Post Crisis, model 6 provides a negative number. Positive number indicates that the means sample firms show abnormal operating performance and outperformed than their average industry. Moreover, negative value in post period comes from two firms namely, PT. Kimia Farma Tbk and PT. Indo Farma Tbk.

Table 2. Indonesian state owned firms

\begin{tabular}{ll}
\hline Model & Nonparametric Wilcoxon $\mathrm{T}$ \\
\hline 1: Two-digit matched $\left(\mathrm{PI}_{\mathrm{i}, \mathrm{t}}{ }^{1}\right)$ & $0.020^{*}$ \\
\hline 2: Four-digit matched $\left(\mathrm{PI}_{\mathrm{i}, \mathrm{t}}{ }^{2}\right)$ & $0.015^{*}$ \\
\hline 3: Two-digit and size-matched $\left(\mathrm{PI}_{\mathrm{i}, \mathrm{t}}{ }^{3}\right)$ & $0.047^{*}$ \\
\hline 4: Lagged ROA and $\Delta$ two-digit matched $\left(\Delta \mathrm{PI}_{\mathrm{i}, \mathrm{t}}{ }^{1}\right)$ & $0.001^{* *}$ \\
\hline 5: Lagged ROA and $\Delta$ four-digit matched $\left(\Delta \mathrm{PI}_{\mathrm{i}, \mathrm{t}}{ }^{2}\right)$ & $0.001^{* *}$ \\
\hline 6: Lagged ROA and $\Delta$ two-digit and size matched $\left(\Delta \mathrm{PI}_{\mathrm{i}, \mathrm{t}}{ }^{3}\right)$ & $0.001^{* *}$ \\
\hline 7: Lagged ROA $\left(\mathrm{P}_{\mathrm{i}, \mathrm{t}-1}\right)$ & 0,363 \\
\hline
\end{tabular}

Significant at the 5\% (*) and $1 \%(* *)$ levels 
In analysing the sub period, the Indonesian family owned firms result shows positive number during pre-crisis, crisis and post crisis period. This positive number reflects that Indonesian family owned firms sample outperformed the average mean score of their industry as shown in Table 3. However, the mean score shows a declining trend due to the companies' slow recovery from the crisis, particularly companies that run property industry. Their negative value makes the average mean during post crisis decrease.

Table 3. Average abnormal operating performance for Indonesian family owned firms

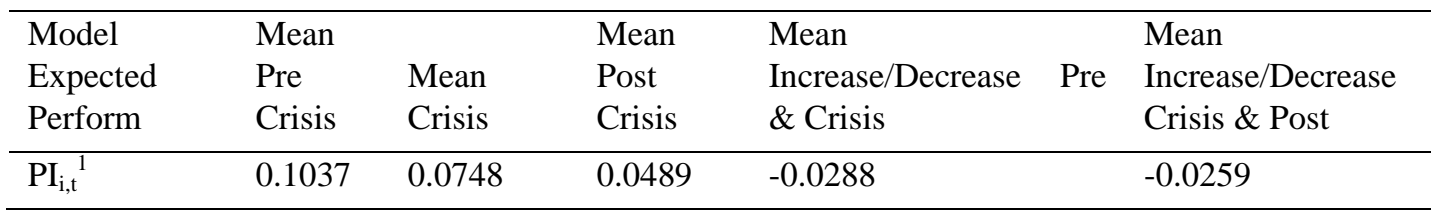

As expected, calculation the average means during crisis declines, possible because of the decreasing performance of the Indonesian state owned firms. However, overall performance of Indonesian state owned firms outperforms their industry as shown in Table 4.

Table 4. Average abnormal operating performance for Indonesian state owned firms

\begin{tabular}{|c|c|c|c|c|c|}
\hline Model & & & Mean & Mean & \\
\hline Expected & Mean Pre & Mean & Post & Increase/Decrease & Mean Increase/Decrease \\
\hline Perform & Crisis & Crisis & Crisis & Pre \& Crisis & Crisis \& Post \\
\hline$\Delta \mathrm{PI}_{\mathrm{i}, \mathrm{t}}^{3}$ & 0.0056 & 0.0135 & -0.0173 & 0.0079 & -0.0308 \\
\hline
\end{tabular}

\subsection{Malaysian Abnormal Operating Performance}

This section presents the results of the abnormal operating performance of the family owned firms and state owned firms in Malaysia. Table 5 presents the results of summary for abnormal operating performance, based on the adjusted $\mathrm{R}^{2}$ and non-parametric Wilcoxon test statistic result. The results show that the family owned firms have model 5 (Lagged firm performance and change in industry performance four digit SIC matched) as the most explanatory power in detecting abnormal operating performance. However, since the rest proposed models are significant, they still qualified as candidates for detecting abnormal operating performance. Finding from pre-crisis and post crisis shows negative value. These results indicate that although Malaysian family owned firms have abnormal operating performance, they still underperform if compared to industry average especially industry with similar four-digit SIC code. However, the result from crisis period shows positive value and the average mean increases. The reason behind this finding is because some companies within the sample recovered quickly from the crisis which eventually contributes to the increase of mean.

Table 5. Malaysian family owned firms

\begin{tabular}{ll}
\hline Model & Nonparametric Wilcoxon $\mathrm{T}$ \\
\hline 1: Two-digit matched $\left(\mathrm{PI}_{\mathrm{i}, \mathrm{t}}{ }^{1}\right)$ & $0.031^{*}$ \\
\hline 2: Four-digit matched $\left(\mathrm{PI}_{\mathrm{i}, \mathrm{t}}{ }^{2}\right)$ & $0.011^{*}$ \\
\hline 3: Two-digit and size-matched $\left(\mathrm{PI}_{\mathrm{i}, \mathrm{t}}{ }^{3}\right)$ & 0,173 \\
\hline 4: Lagged ROA and $\Delta$ two-digit matched $\left(\Delta \mathrm{PI}_{\mathrm{i}, \mathrm{t}}{ }^{1}\right)$ & $0.001^{* *}$ \\
\hline 5: Lagged ROA and $\Delta$ four-digit matched $\left(\Delta \mathrm{PI}_{\mathrm{i}, \mathrm{t}}{ }^{2}\right)$ & $0.001^{* *}$ \\
\hline 6: Lagged ROA and $\Delta$ two-digit and size matched $\left(\Delta \mathrm{PI}_{\mathrm{i}, \mathrm{t}}{ }^{3}\right)$ & 0,069 \\
\hline 7: Lagged ROA $\left(\mathrm{P}_{\mathrm{i}, \mathrm{t}-1}\right)$ & 0,609 \\
\hline
\end{tabular}

Significant at the 5\%(*) and $1 \%(* *)$ levels 
Table 6 presents the results of the abnormal operating performance of the state owned firms in Malaysia. The results show that for the state owned firms, the result shows that model 3 (Level of industry performance with two-digit SIC and size matched) is the model with the most explanatory power level of industry performance. The result shows positive value during three sub periods. Table 6 also shows that in Crisis period model 5 gives positive figure which reveals that sample firms outperformed the average mean score of the industry. The reason behind this finding is due to several companies within the sample recovered early from crisis; hence these several companies contribute to increase of mean. Sub period analysis for the Malaysian state owned Firms shows no significant movement.

Table 6. Malaysian state owned firms

\begin{tabular}{ll}
\hline Model & Nonparametric Wilcoxon $\mathrm{T}$ \\
\hline 1: Two-digit matched $\left(\mathrm{PI}_{\mathrm{i}, \mathrm{t}}{ }^{1}\right)$ & $0.003^{* *}$ \\
\hline 2: Four-digit matched $\left(\mathrm{PI}_{\mathrm{i}, \mathrm{t}}{ }^{2}\right)$ & $0.008^{* *}$ \\
\hline 3: Two-digit and size-matched $\left(\mathrm{PI}_{\mathrm{i}, \mathrm{t}}{ }^{3}\right)$ & $0.036^{*}$ \\
\hline 4: Lagged ROA and $\Delta$ two-digit matched $\left(\Delta \mathrm{PI}_{\mathrm{i}, \mathrm{t}}{ }^{1}\right)$ & $0.001^{* *}$ \\
\hline 5: Lagged ROA and $\Delta$ four-digit matched $\left(\Delta \mathrm{PI}_{\mathrm{i}, \mathrm{t}}{ }^{2}\right)$ & $0.001^{* *}$ \\
\hline 6: Lagged ROA and $\Delta$ two-digit and size matched $\left(\Delta \mathrm{PI}_{\mathrm{i}, \mathrm{t}}{ }^{3}\right)$ & $0.001^{* *}$ \\
\hline 7: Lagged ROA $\left(\mathrm{P}_{\mathrm{i}, \mathrm{t}-1}\right)$ & 0,334 \\
\hline
\end{tabular}

Significant at the 5\% (*) and $1 \%(* *)$ levels

The positive value indicates that Malaysian State Owned firms outperform their average industry. Further observation in sub period, Malaysian Family Owned Firms result shows models 5 giving negative number during pre crisis and post crisis. These results provide implication that Malaysian family owned firms have abnormal operating performance and underperform when compared to industry average especially industry with similar four-digit SIC code.

Table 7. Average abnormal performance for Malaysian family owned firms

\begin{tabular}{llllll}
\hline $\begin{array}{l}\text { Model } \\
\text { Expected }\end{array}$ & Mean Pre & Mean & Mean & Mean & Post \\
Perform & Crisis & Crisis & Crisis & $\begin{array}{l}\text { Increase/Decrease } \\
\text { Pre \& Crisis }\end{array}$ & $\begin{array}{l}\text { Mean Increase/Decrease } \\
\text { Crisis \& Post }\end{array}$ \\
\hline$\Delta \mathrm{PI}_{\mathrm{i}, \mathrm{t}}{ }^{2}$ & $-0,0001$ & 0,0081 & $-0,0089$ & 0,0083 & $-0,0171$ \\
\hline
\end{tabular}

The result shows that most of sample firms that underperform are companies that run property industry as shown in Table 8. As expected, the average mean score during the crisis declines, possible because of the decreasing performance of the Indonesian state owned firms. However, overall performance of Indonesian state owned firms outperforms their industry as shown in Table 8.

Table 8. Average abnormal performance for Malaysian state owned firms

\begin{tabular}{|c|c|c|c|c|c|}
\hline $\begin{array}{l}\text { Model } \\
\text { Expected } \\
\text { Perform }\end{array}$ & $\begin{array}{l}\text { Mean Pre } \\
\text { Crisis }\end{array}$ & $\begin{array}{l}\text { Mean } \\
\text { Crisis }\end{array}$ & $\begin{array}{l}\text { Mean } \\
\text { Post } \\
\text { Crisis }\end{array}$ & $\begin{array}{l}\text { Mean } \\
\text { Increase/Decrease } \\
\text { Pre \& Crisis }\end{array}$ & $\begin{array}{l}\text { Mean Increase/Decrease Crisis } \\
\& \text { Post }\end{array}$ \\
\hline $\mathrm{PI}_{\mathrm{i}, \mathrm{t}}{ }^{3}$ & 0,1295 & 0,0519 & 0,0774 & $-0,0776$ & 0,0254 \\
\hline
\end{tabular}




\section{Conclusion}

This study examines the financial performance of family owned firms and state owned firms listed in Bursa Malaysia and the Indonesia Stock Exchange. This study relied on the type of measurement for performance comparison between family and state owned firms are Abnormal Operating Performance. This measurement captures a firm's financial performance. In addition, this study evaluates methods used in studies that employ accounting-based measures of operating performance and also examines the choice of an accounting-based performance measure, a statistical test, and a model of expected operating performance. The result defines the specification and power of tests designed to detect abnormal operating performance. This study shows that the state owned firms outperformed the family owned firms in Indonesia and Malaysia. Hence, the family owned firms need to strategize on how to increase its competitive advantage in order to compete with the state owned firms especially if they are competing in similar industry. Based on abnormal operating performance result, for each type of ownership which have model that have influenced by changing in their internal company or changing within their industry, they need to consider all factors that can impact their performance.

This study is not without limitations. First, this study focuses only on the family owned enterprises and the state owned enterprises in Indonesia and Malaysia since Claessens et al study (2000) reported that Indonesia has the highest percentage of firms with family ownership, followed by Malaysia. Meanwhile, Malaysia has the second highest percentage of firms with state ownership, followed by Indonesia. Secondly, Indonesia and Malaysia have the same characteristics in terms of various ethnicities. Thirdly, in classifying the sample of family owned firms, this study observed the majority of shareholders of each firm in determining whether the firm belongs to one family or is managed by the family member. Nevertheless, Indonesia do not use surname and majority shareholder of listed firms. Finally, due to limited data, this study relied on three inputs and two outputs for those firms. In addition, since the data used by this study was collected from the public listed companies, the results should be confined and applicable to this group of companies only. The findings in this study shed some new light into literature on family and government involvement in company and their performance. And it may contribute to the existing literature by providing a new data set on family and government owned companies in both countries.

\section{Acknowledgement}

We wish to thank the Institute of Quality and Knowledge Advancement, Universiti Teknologi MARA for their support and funding.

\section{References}

Ab-Razak, H., Ahmad, R., \& Aliahmed, H. J. (2008). Government Ownership and Performance: An Analysis of Listed Companies in Malaysia. Social Science Research Network. https://doi.org/10.22495/cocv6i2c4p2

Barber, B., \& Lyon, J. (1996). Detecting abnormal operating performance: The Empirical power and specification of test statistics. Journal of Financial Economics, 41, 359-400. https://doi.org/10.1016/0304-405X(96)84701-5

Barbosa, N., \& Louri, H. (2002). On the determinants of multinationals' ownership preferences: evidence from Greece and Portugal. International Journal of Industrial Organization, 20, 493-515. https://doi.org/10.1016/S0167-7187(00)00102-8

Berle, A., \& Means, G. (1932). The Modern Corporation and Private Property. MacMillan, New York, New York.

Castorena, O. H., Enríquez, L. A., \& Adame, M. G. (2014). The Influence of Information Technology and Communication Supply Chain Management Performance for Greater SME Manufacturing in Aguascalientes. International Journal of Business, Economics and Management, 1(12), 382-396.

Che, G. N., \& Sundjo, F. (2018). Determinants of Female Labour Force Participation in Cameroon. International Journal of Applied Economics, Finance and Accounting, 3(2), 88-103. https://doi.org/10.33094/8.2017.2018.32.88.103

Cheng, C. P., Phung, M. T., Hsiao, C. L., Shen, D. B., \& Chen, B. S. (2018). Impact of Operational Risk Toward the Efficiency of Banking-Evidence from Taiwans Banking Industry. Asian Economic and Financial Review, 8(6), 815-831. https://doi.org/10.18488/journal.aefr.2018.86.815.831

Chowdhury, T. S., Habibullah, M., \& Nahar, N. (2018). Risk and Return Analysis of Closed-End Mutual Fund in Bangladesh. Journal of Accounting, Business and Finance Research, 3(2), 83-92. https://doi.org/10.20448/2002.32.83.92

Claessens, S., Djankov, S., \& Lang, L. (2000). The separation of ownership and control in East Asian Corporations. 
Journal of Financial Economics, 58(1-2), 81-112. https://doi.org/10.1016/S0304-405X(00)00067-2

Claessens, S., \& Fan, J. (2002). Corporate Governance in Asia: A Survey. International Review of Finance, 3(2), 71-103. https://doi.org/10.1111/1468-2443.00034

Claessens, S., Djankov, S., Fan, F., \& Lang, L. (2002). Disentangling the Incentive and Entrenchment Effects of Large Shareholdings. Journal of Finance, 57(6), 2741-2771. https://doi.org/10.1111/1540-6261.00511

Coase, R. H. (1937). The nature of the firm. Economica, 4(16), 368-405. https://doi.org/10.1111/j.1468-0335.1937.tb00002.x

Davis, P. (1983). Realizing the potential of the family business. Organizational Dynamics, 12(1), Summer, 47-56. https://doi.org/10.1016/0090-2616(83)90026-8

Demsetz, H. (1983). The structure of ownership and the theory of the firm. Journal of Law and Economics, 25, 375-390. https://doi.org/10.1086/467041

Demsetz, H., \& Villalonga, B. (2001). Ownership Structure and Corporate Performance. Journal of Corporate Finance, 7(3), 209-233. https://doi.org/10.1016/S0929-1199(01)00020-7

Dim, N. U., \& Ezeabasili, A. C. C. (2015). Strategic supply chain framework as an effective approach to procurement of public construction projects in Nigeria. International Journal of Management and Sustainability, 4(7), 163-172. https://doi.org/10.18488/journal.11/2015.4.7/11.7.163.172

Duru, P. N., \& Chibo, C. N. (2014). Flooding in Imo State Nigeria: The Socio-Economic Implication for Sustainable Development. Humanities and Social Sciences Letters, 2(3), 129-140.

Grossman, S., \& Hart, O. (1980). The Costs and Benefits of Ownership: A Theory of Vertical and Lateral Integration. Bell Journal of Economics, 11, 42-64. https://doi.org/10.2307/3003400

James, H. (1999). Owner as manager, extended horizons and the family firm. International Journal of Economics and Business, 6, 41-56.

Jensen, M. C. (1983), Organization Theory and Methodology. Accounting Review, 50(2), 319-39.

Kimengsi, J. N., \& Gwan, S. A. (2017). Reflections on Decentralization, Community Empowerment and Sustainable Development in Cameroon. International Journal of Emerging Trends in Social Sciences, 1(2), 53-60. https://doi.org/10.20448/2001.12.53.60

Kocenda, E., \& Svejnar, J. (2002). The Effects of Ownership Forms and Concentration on Firm Performance after Large-Scale Privatization. William Davidson Institute Working Paper Number 471. https://doi.org/10.2139/ssrn.314480

Lansberg, I. (1983). Managing human resources in family firms: The problem of institutional overlap. Organizational Dynamics, Summer, 39-46. https://doi.org/10.1016/0090-2616(83)90025-6

Lassere, P., \& Schutte, H. (1999). Strategies for Asia Pacific: Beyond the Crisis. South Yarra, Macmillan Business. https://doi.org/10.1007/978-1-349-14857-8

Mitton, T., (2002). A cross-firm analysis of the impact of corporate governance on the East Asian financial crisis. Journal of Financial Economics, 64, 215-241. https://doi.org/10.1016/S0304-405X(02)00076-4

Nazal, A. I. (2017). Financial Tables Reports Gaps in Jordanian Islamic Banks. The Economics and Finance Letters, 4(2), 9-15. https://doi.org/10.18488/journal.29.2017.42.9.15

Nze, I. C., Ogwude, I. C., Nnadi, K. U., \& Ibe, C. C. (2016). Modelling the Relationship between Demand for River Port Services and Vessel Supply Costs: Empirical Evidence from Nigeria. Global Journal of Social Sciences Studies, 2(3), 144-149.

Purnama, C. (2014). Improved Performance Through Empowerment of Small Industry. Journal of Social Economics Research, 1(4), 72-86.

Samad, M. F. A., Amir, A., \& Ibrahim, H. (2008). Board structure and corporate performance: Evidence from public-listed family-ownership in Malaysia. https://doi.org/10.2139/ssrn.1292182

Schleifer, A., \& Vishny, R. (1997). A survey of corporate governance. Journal of Finance, 52, 737-783. https://doi.org/10.1111/j.1540-6261.1997.tb04820.x

Shleifer, A., \& Summers, L. (1988). Breach of trust in hostile takeovers. In A. Auberback (Ed.), Corporate takeovers: Causes and consequences. Chicago, IL: University of Chicago Press. https://doi.org/10.3386/w2342 
Singh, R., \& Jayraman, V. (2013). Supply chain integration and information technology. International Journal of Economics Business and Management Studies, 2(2), 62-74.

Tanoos, J. J. (2017). East Asian Trade Cooperation versus US and EU Protectionist Trends and their Association to Chinese Steel Exports. Asian Journal of Economics and Empirical Research, 4(1), 1-7. https://doi.org/10.20448/journal.501.2017.41.1.7

Taqi, M., Ajmal, M., \& Ansari, M. S. (2018). Financial Efficiency of India Tourism Development Corporation (ITDC) Limited: An Empirical Study. Journal of Tourism Management Research, 5(1), 14-22. https://doi.org/10.18488/journal.31.2018.51.14.22

Wang, Y. B., \& Lu, J. R. (2016). A Supply-Lock Competitive Market for Investable Products. Asian Development Policy Review, 4(4), 127-133. https://doi.org/10.18488/journal.107/2016.4.4/107.4.127.133

Wong, S. C. Y. (2004). Improving Corporate Governance in SOEs: An Integrated Approach. Corporate Governance International, $7(2)$. 